\title{
Socio-personal contour, Information flow and Productivity of Brackishwater aquaculture systems - An Appraisal
}

\author{
M. Kumaran ${ }^{1}$, M. Sundaram ${ }^{2}$, Shijo Mathew ${ }^{3}$ and PR.Anand ${ }^{4}$
}

\begin{abstract}
Brackishwater aquaculture, the farming of shrimps and fishes in coastal areas is practiced both in traditional and scientific methods. A study was conducted to assess the connectedness between the profile characteristics, their information sourcing and productivity levels. The study indicated that systems and states differ significantly $(p<0.01)$ both in terms of profile status and productivity levels. Private extension services were dominant in scientific farming while traditional systems depend on state fisheries departments for inputs and technical advisory. Therefore, taking into account the relative strengths the state departments may partner with research institutions and input companies respectively for technology support and reaching the farmers located in remote locations. Mobile phone applications may be developed and launched for connecting the technology, inputs, services and market with the farming community.
\end{abstract}

Keywords : Brackishwater aquaculture; information flow; mobile application; socio-economics; Kerala; West Bengal

\section{INTRODUCTION}

Brackishwater aquaculture is the farming of shrimps and fishes in ponds using brackishwater which is being adopted in about 2.0 lakh ha along the coastal regions. India has a brackishwater potential of 1.2 million ha and out of which $15 \%$ is alone put in to use for fish production at present. Traditionally brackishwater aquaculture was practiced in the form of 'trap and hold' system wherein the fishes come in the high tide waters were trapped, reared and caught as 'continuous stocking and continuous harvesting mode' as a livelihood avocation. Scientific advancements aided induced seed production and feed processing technologies evolved the scientific brackishwater aquaculture which is relatively intensive with prescribed stocking density and inputs to produce marketable size of shrimp i.e 20-30 g in about 120-130 days. Scientific brackishwater aquaculture is a commercial activity with relatively higher investments, high risk and high profit model. However, in states like West Bengal and Kerala both

1. Principal Scientist, 2, 3, \& 4, Research Scholars, ICAR-Central Institute of Brackishwater Aquaculture, 75, Santhome High Road, Chennai - 600028. 
traditional and scientific mode of aquaculture is being taken up. Traditional shrimp farming in Kerala as Chemmeen kettu in pokkali fields and bheris in West Bengal has been practiced for centuries and still continued without much interventions in the technological aspects making them a low cost - low profit sustainable production system (Kiran and Salim, 2012). Considering the inputs used and practices adopted Chandrasekaran et al (2009) viewed that traditional brackishwater aquaculture systems is tantamount to organic aquaculture. It is a common perception that socio-economic profile of producers and access to improved technology would led to enhanced productivity. However, such hypothesis needs to be validated in aquaculture. Therefore, the present investigation was taken up to examine the connectedness between the profile characteristics of brackishwater aquaculture farmers, their information sourcing and the productivity levels.

\section{METHODOLOGY}

The present investigation was taken up in West Bengal (WB) and Kerala (KL) states where both traditional and modern modes of brackishwater aquaculture are adopted. Tidefed auto stocking of fish and shrimp seeds without much farm management was the phenomenon of traditional systems. Whereas, scientific farms adopted the package of practices recommended throughout the cropping cycle. A respective sample of 45 and 22 scientific farmers in WB and $\mathrm{KL}$ ( 67 ) and a sample of 21 and 84 (105) traditional farmers respectively in $\mathrm{WB}$ and $\mathrm{KL}$ were selected using proportionate random sampling procedure to collect the primary data for the study in tune with the systems of farming practised in these states. The sociopersonal characteristics of aquafarmers were studied through 16 variables viz., gender, age, educational status, occupation, family type, family size, family annual income, community, farming experience, social participation, farm ownership, farm size, employment generation, farm infrastructure, training attended and cropping intensity. Farmers' access to technology information was ascertained through information sources and preferred mode of information delivery. The socio-economic characteristics and access to information data were pooled as personal profile of the respondents system and state wise to compare and interpret the data contextually. Production particulars of the systems were measured on the basis of stocking density, feed conversion ratio, production cost, crop duration, sale price and cost benefit ratio of the systems. Appropriate scoring and measurement procedures were employed to collect the data. The primary data were collected through personal contact survey using a pre-tested structured questionnaire. The data collected were cleaned and subjected to descriptive statistics viz., frequency, mean, standard deviation and percentage analysis for data consolidation. Kruskal-Wallis analysis a non-parametric test was employed to compare the results across the states and systems to ascertain the 
samples connectedness in terms of origination from the same distribution.

\section{FINDINGS AND DISCUSSION}

\section{Socio-Personal Characteristics of Brackishwater Aquaculture Farmers}

The socio-economic data of farmers practicing traditional and modern brackishwater aquaculture systems are presented in the Table-1. The data indicate that aqua farmers irrespective of the system and states were males and involvement of women folk was negligible due to remote farming locations, timings and nature of farming operations. In case of age, majority of the traditional (58\%) and scientific (76\%) farmers of West Bengal were belonged to 31-45 years. Contrarily, half of scientific (54\%) and traditional (49\%) farmers of Kerala $(\mathrm{KL})$ were in the age group of 46-60 years. This signifies that the farmers of WB were relatively young compared to that of Kerala and the entrepreneurial nature of scientific shrimp farming attracted more youth rather than traditional systems. In case of educational levels about $50 \% \mathrm{KL}$ farmers were graduates, but 60 to $90 \%$ of WB respondents irrespective of the systems had education up to matric level only, which is in line with the literacy levels of the respective states. Therefore, extension programmes and farming literature for WB farmers need to be prepared in their local language.

Aquaculture was the primary occupation for majority of the respondents irrespective of the system and state, however, in $\mathrm{KL}$ it was an additional occupation for 30$40 \%$ of farmers. It was observed during the survey that many aqua farmers were either employed or had other businesses in addition to farming. This could be one of the reasons for slow progress of aquaculture vis-à-vis the resource potential available in the state. Majority of the scientific farmers in $\mathrm{KL}$ (86\%), traditional farmers of WB (62\%) and KL (81\%) were lived in nuclear families. However, majority of the scientific farmers in WB (62\%) lived as joint families. This is because of the economics involved and requirement of own manpower to manage shrimp farming.

Majority of scientific farmers of WB (57.78\%) and around half of traditional $\mathrm{KL}$ farmers (47.60\%) reported that their annual income was up to Rs.2, 40,000. Farm size and system of production could be the reason for the reported income levels by the scientific farmers in WB. More than half of scientific farmers in $\mathrm{KL}$ (54\%), and traditional farmers of WB (58\%) reported that their income levels were between Rs. 2, 40,000 to Rs.4,80,000 per annum. Majority of WB (89\%), one third of $\mathrm{KL}(36.36 \%)$ shrimp farmers and majority of traditional farmers both in WB (62\%) and $\mathrm{KL}$ (52.40\%) had a farming experience of less than 10 years. This is in tune with their age categories reported earlier and the tenure nature of systems. Majority of WB (93.33\%) and $\mathrm{KL}(59 \%)$ farmers and $50 \%$ of traditional $\mathrm{KL}$ farmers had associated with formal or informal social institutions formed for the welfare of farmers. 
Table 1.

Socio-economic Status of Brackishwater Aquaculture Farmers

\begin{tabular}{|c|c|c|c|c|c|}
\hline \multirow[b]{2}{*}{ SI. No } & \multirow{2}{*}{$\begin{array}{c}\text { Socio-economic } \\
\text { characteristics }\end{array}$} & \multicolumn{2}{|c|}{ Scientific systems } & \multicolumn{2}{|c|}{ Traditional systems } \\
\hline & & $\begin{array}{c}\text { West Bengal } \\
\text { (n1=45) }\end{array}$ & $\begin{array}{c}\text { Kerala } \\
\text { (n2=22) }\end{array}$ & $\begin{array}{l}\text { West Bengal } \\
\qquad(\mathrm{n} 3=21)\end{array}$ & $\begin{array}{c}\text { Kerala } \\
\text { (n4=84) }\end{array}$ \\
\hline 1 & \multicolumn{5}{|c|}{ Gender } \\
\hline & Male & 97.77 & 95.45 & 100.00 & 96.40 \\
\hline & Female & 2.22 & 4.55 & 0.00 & 3.60 \\
\hline 2 & \multicolumn{5}{|c|}{ Age in years } \\
\hline & Up to 30 years & 17.77 & 9.09 & 9.50 & 4.80 \\
\hline & 31 - 45 years & 57.77 & 13.63 & 76.10 & 27.30 \\
\hline & $46-60$ years & 20.00 & 54.54 & 9.60 & 48.80 \\
\hline & Above 61 years & 4.44 & 22.72 & 4.80 & 19.00 \\
\hline 3 & \multicolumn{5}{|c|}{ Educational status } \\
\hline & Up to Middle School & 35.55 & 9.09 & 100.00 & 17.80 \\
\hline & Matriculate level & 62.22 & 40.90 & 0.00 & 60.70 \\
\hline & Graduate & 2.22 & 49.99 & 0.00 & 21.50 \\
\hline 4 & \multicolumn{5}{|c|}{ Occupation } \\
\hline & Aquaculture as Primary & 75.55 & 59.09 & 100.00 & 69.00 \\
\hline & Aquaculture as additional & 24.44 & 40.90 & 0.00 & 31.00 \\
\hline 5 & \multicolumn{5}{|c|}{ Family status } \\
\hline & Joint family & 62.22 & 13.63 & 38.00 & 19.00 \\
\hline & Nuclear family & 37.78 & 86.36 & 62.00 & 81.00 \\
\hline \multirow[t]{3}{*}{6} & Family Size & & & & \\
\hline & Up to 4 members & 62.22 & 54.54 & 66.6 & 71.40 \\
\hline & Above 4 members & 37.78 & 45.45 & 33.4 & 28.60 \\
\hline 7 & \multicolumn{5}{|c|}{ Family annual income in Rs. } \\
\hline & < Rs.2.4 Lakh & 57.78 & 18.18 & 38.00 & 47.60 \\
\hline & Rs.2.41 to 4.8 Lakh & 4.00 & 54.54 & 62.00 & 39.30 \\
\hline & > Rs.4.8Lakh & 2.22 & 27.27 & 0.00 & 13.10 \\
\hline 8 & \multicolumn{5}{|c|}{ Community } \\
\hline & GEN & 93.33 & 13.63 & 100.00 & 11.90 \\
\hline & $\mathrm{OBC}$ & 0.00 & 81.81 & 0.00 & 79.80 \\
\hline & SC/ ST & 6.66 & 4.54 & 0.00 & 8.30 \\
\hline
\end{tabular}


Socio-personal contour, Information flow and Productivity of Brackishwater aquaculture systems - An Appraisal

\begin{tabular}{|c|c|c|c|c|c|}
\hline \multirow[b]{2}{*}{ Sl. No } & \multirow{2}{*}{$\begin{array}{l}\text { Socio-economic } \\
\text { characteristics }\end{array}$} & \multicolumn{2}{|c|}{ Scientific systems } & \multicolumn{2}{|c|}{ Traditional systems } \\
\hline & & $\begin{array}{l}\text { West Bengal } \\
\quad(n 1=45)\end{array}$ & $\begin{array}{c}\text { Kerala } \\
\text { (n2=22) }\end{array}$ & $\begin{array}{l}\text { West Bengal } \\
\quad(\mathrm{n} 3=21)\end{array}$ & $\begin{array}{c}\text { Kerala } \\
\text { (n4= 84) }\end{array}$ \\
\hline 9 & \multicolumn{5}{|c|}{ Farming experience in years } \\
\hline & Up to 10 years & 88.89 & 36.36 & 61.9 & 52.40 \\
\hline & 11 to 20 years & 6.66 & 45.45 & 28.6 & 21.40 \\
\hline & 21 years $\&$ above & 4.44 & 18.18 & 9.5 & 26.20 \\
\hline 10 & \multicolumn{5}{|c|}{ Social Participation } \\
\hline & Associated & 93.33 & 59.09 & 0.00 & 50.00 \\
\hline & Not associated & 6.67 & 40.90 & 100 & 50.00 \\
\hline 11 & \multicolumn{5}{|c|}{ Farm ownership } \\
\hline & Owned & 93.33 & 31.81 & 0.00 & 83.3 \\
\hline & Leased & 6.66 & 68.18 & 100.00 & 16.7 \\
\hline 12 & \multicolumn{5}{|c|}{ Farm size in ha } \\
\hline & Up to 2 ha & 91.11 & 50.00 & 52.3 & 67.9 \\
\hline & 2.1 to 5.0 ha & 6.66 & 40.90 & 38.2 & 14.28 \\
\hline & Above 5 ha & 2.22 & 9.09 & 9.5 & 10.71 \\
\hline 13 & $\begin{array}{l}\text { Avg.no. of days employed } \\
\text { in aquaculture }\end{array}$ & $212 \pm 49.95$ & $\begin{array}{c}210.68 \pm \\
76.28\end{array}$ & $295 \pm 16.78$ & $216.8 \pm 64.4$ \\
\hline 14 & $\begin{array}{l}\text { Farm infrastructure \& } \\
\text { biosecurity }\end{array}$ & $6.26 \pm 1.22$ & $4.0 \pm 1.59$ & $2.0 \pm 0.0$ & $2.5 \pm 1.3$ \\
\hline 15 & $\begin{array}{l}\text { Training attended on } \\
\text { aquaculture }\end{array}$ & 86.67 & 50.00 & 0.00 & 61.90 \\
\hline 16 & \multicolumn{5}{|c|}{ Cropping intensity } \\
\hline & One & 22.22 & 13.64 & 100 & 5.95 \\
\hline & Two & 75.55 & 86.36 & 0.00 & 64.05 \\
\hline
\end{tabular}

Majority of scientific shrimp farmers in WB (93.33\%) and traditional farmers in $\mathrm{KL}$ (83.30\%) had their own farms whereas majority of scientific farmers in $\mathrm{KL}$ (68.18\%) and all the bheries in WB were leased farms. Bheries were large embankments made by joining small plots owned by many individuals of varying size and a big firm or farmer took these lands on lease for taking up aquaculture. Majority of scientific farms in WB (91.11\%), KL (50\%) and traditional farmers in WB (52.30\%) and $\mathrm{KL}$ (67.90\%) were small farms less with than 2 ha. This may be due to the land reforms taken place in these states. While scientific aquaculture provided employment for 210 to 222 days in a year, the traditional farms provided 217 to 295 days employment for the local people. Scientific farms had better infrastructure and biosecurity measures than their traditional counter parts as the former are technology 
driven production systems. Majority of WB (87\%), and $50 \%$ of the scientific farmers in $\mathrm{KL}$ had attended one or other structured training on aquaculture. Aquaculture being a technology intensive farming participation in training on the subject could give the required knowledge and skill. The research centre of ICAR-CIBA at Kakdwip in south 24 Parganas district of WB trained the shrimp farmers in WB on the Better Management Practices (BMPs) which might be the reason for many farmers to takeup farming of Pacific white shrimp (Penaeus vannamei) in that area.

\section{Information Seeking and Communication behaviour of farmers}

Farmers approach fisheries departments and institutions for technical advisories. The data given in the Table-2 show that most of the traditional farmers in WB (100\%) and $K L(64 \%)$ were dependent on public funded extension systems like Department of Fisheries and offices of MPEDA. However, in case of scientific shrimp farming, respondents are dependent on private extension service providers like feed company technicians and aquaculture consultants(44 and 50\%) in both the states. Itwas informed that feed technicians were the primary source of information on the technical matters as they were accessible at any time and visited their client farms at weekly intervals for follow up. The farmers generally cross check the information obtained from other sources with their fellow farmers. Farmers approached MPEDA for development subsidy and market related information. In Kerala, DoF had implemented several subsidy oriented schemes for the development of aquaculture and provided 40,000 shrimp seed at free of cost to farmers. However, there was no technical support from the DoF and the farmers dependent on consultants and fellow progressive farmers. Scientific shrimp farmers need technology information constantly to minimize the risk factors in the production cycle. Most of the respondents irrespective of the system preferred that group meetings at monthly intervals were the desired mode of communication to receive technical guidance. Group meetings were preferred as it provided them the opportunity for horizontal learnings among the farmers and discuss the issues in an understandable manner.

Table 2.

Access and Preferred mode of communication for Brackishwater aquaculture farmers

\begin{tabular}{|c|l|c|c|c|c|}
\hline \multirow{3}{*}{ S1. No } & \multirow{2}{*}{$\begin{array}{l}\text { Access and preferred } \\
\text { mode communication }\end{array}$} & $\begin{array}{l}\text { Scientific systems } \\
\text { West Bengal } \\
(\mathbf{n} 1=45)\end{array}$ & $\begin{array}{l}\text { Kerala } \\
(\mathbf{n} 2=22)\end{array}$ & $\begin{array}{l}\text { Traditional systems } \\
(\mathbf{n} 3=21)\end{array}$ & $\begin{array}{l}\text { Kest Bengala } \\
(\mathbf{n} 4=84)\end{array}$ \\
\hline \multirow{3}{*}{1} & & & & & \\
\cline { 2 - 6 } & Access to e-mail \& internet & & & & \\
\cline { 2 - 6 } & Yes & 97.78 & 40.90 & 0.00 & 78.6 \\
\cline { 2 - 6 } & No & 2.22 & 59.09 & 100 & 21.4 \\
\hline
\end{tabular}


Socio-personal contour, Information flow and Productivity of Brackishwater aquaculture systems - An Appraisal

\begin{tabular}{|c|c|c|c|c|c|}
\hline 2 & \multicolumn{5}{|c|}{ Information seeking Behaviour } \\
\hline & $\begin{array}{l}\text { Public Funded Extension } \\
\text { (DOF, MPEDA, Res.Instt.) }\end{array}$ & 17.77 & 27.27 & 100.00 & 64.4 \\
\hline & $\begin{array}{l}\text { Private Extension } \\
\text { (Consultants \& Feed } \\
\text { company Technicians) }\end{array}$ & 44.44 & 49.99 & 0.00 & 16.70 \\
\hline & Progressive Farmers & 37.79 & 22.74 & 0.00 & 17.90 \\
\hline \multirow[t]{5}{*}{4} & $\begin{array}{l}\text { Preferred mode of } \\
\text { communication }\end{array}$ & & & & \\
\hline & Printed matter & 0.00 & 4.54 & 0.00 & 9.50 \\
\hline & E-mail & 0.00 & 4.54 & 0.00 & 0.00 \\
\hline & Mobile SMS & 4.44 & 4.54 & 0.00 & 10.7 \\
\hline & Group meeting & 95.56 & 86.36 & 100.00 & 79.8 \\
\hline \multirow[t]{4}{*}{4} & $\begin{array}{l}\text { Frequency of information } \\
\text { required }\end{array}$ & & & & \\
\hline & Weekly & 6.66 & 4.54 & 0.00 & 5.95 \\
\hline & Fortnightly & 2.22 & 0.00 & 0.00 & 0.00 \\
\hline & Monthly & 91.11 & 95.45 & 100.00 & 90.5 \\
\hline \multirow{2}{*}{\multicolumn{2}{|c|}{$\begin{array}{l}\text { Profile status (socio-economic } \\
\text { and information \& communication } \\
\text { behaviour) across the systems and } \\
\text { states and their connectedness. }\end{array}$}} & $20.82 \pm 2.89$ & $\begin{array}{c}22.36 \pm \\
3.37\end{array}$ & $\begin{array}{c}15.61 \pm \\
1.75\end{array}$ & $\begin{array}{c}16.78 \pm \\
3.00\end{array}$ \\
\hline & & & $\begin{array}{l}\text { al Wallis } t \\
\text {-Square } \mathrm{s} \\
\text { * significa }\end{array}$ & $\begin{array}{l}\text { f significa } \\
=61.667^{*} \\
1 \% \text { level }\end{array}$ & \\
\hline
\end{tabular}

The data on socio-personal and information access were pooled together to have a better indication about the profile of the respondents. The Kruskal Wallis test of significance done to assess the connectedness between the samples of states and systems showed that the respondents differ significantly $(p<0.01)$ both in terms systems and states in terms of their profile status (Table-2). It is obvious that the scientific shrimp farmers had better education, higher income and better access to technology than their traditional counterparts. Similarly the $K L$ respondents had a better profile vis-à-vis their WB counterparts which might be due to their differential nature of farming systems, educational, income and information seeking behaviour.

Productivity parameters of traditional and scientific shrimp farming

It may be noticed from the Table- 3 that traditional systems adopted an average seed stocking density of 4.8 numbers of shrimp 
Post Larvae (PL) per square meter or 48,000 larvae in one ha whereas the average stocking density followed in scientific farming was 35 PLs/ sq. m. Average seed stocking density is the indicator to determine the scale of farming. In case of $\mathrm{KL}$ the seed was given by the state government as a welfare measure at free of cost to traditional shrimp farms. Traditional shrimp farms were auto fed, the supplementary seed stocked were of poor quality, applied homemade feeds and farm management were inadequate. However, scientific farms used formulated highly balanced feed and adopted efficient feed management. Nevertheless the feed requirement for producing one kilogram of shrimp in both the systems were almost was $22 \mathrm{~g}$. same but the cost of feed in scientific farming was Rs.85 per kg and in case of traditional systems rice brawn, out dated wheat breads and oil cakes were used as feed and it was costing hardly Rs.40-50/kg. This was evident in the cost of production in the systems as it was Rs.248/Kg in scientific farming and Rs.183/kg in case of traditional systems. The average production in traditional systems was $1.0 \mathrm{t} / \mathrm{ha}$ where as in case of scientific farming it was $5.4 \mathrm{t} / \mathrm{ha}$. However, the crop duration was more (144 days) in traditional systems because they preferred bigger sized shrimps up to 35-40 g which fetched them higher market price of Rs.450-500 per kg. Whereas in scientific farming the duration was 115-120 days and the average size of shrimp harvested

Table 3.

Production parameters of traditional and scientific shrimp production systems

\begin{tabular}{|c|l|c|c|}
\hline SI. No & \multicolumn{1}{|c|}{ Parameters } & Scientific $(\mathbf{n} 1=67)$ & Traditional $(\mathbf{n}$ = 105) \\
\hline 1 & Stocking density $\left(\mathrm{PL} / \mathrm{m}^{2}\right)$ & $35.1 \pm 14.7$ & $4.8 \pm 1.5$ \\
\hline 2 & Feed Conversion Ratio (FCR) & $1.4 \pm 0.2$ & $1.3 \pm 0.1$ \\
\hline 3 & Cost of production in Rs. & $248 \pm 58$ & $183.3 \pm 56.1$ \\
\hline 4 & Crop duration in days & $114 \pm 11.5$ & $144 \pm 9.9$ \\
\hline 5 & Production tonnes/ha/crop & $5.4 \pm 3.2$ & $1.0 \pm 0.7$ \\
\hline 6 & Size at harvest in g & $21.5 \pm 10.6$ & $35 \pm 6.0$ \\
\hline 7 & Market price in Rs. & $357 \pm 35.2$ & $446.1 \pm 87.2$ \\
\hline
\end{tabular}

\begin{tabular}{l|l}
8 & Cost Benefit Ratio
\end{tabular}

Though volume wise scientific farms yielded higher productivity, the profitability was high in case of traditional shrimp farming considering the shrimp price and cost of production. However, higher production achieved in scientific farming enhanced their profitability. Bhattacharya (2009) reported

\begin{tabular}{l|l}
\hline $1.48 \pm 0.5$ & $2.3 \pm 0.5$
\end{tabular}

similar findings indicating higher benefit cost ratio for traditional shrimp farming than the scientific shrimp farming. It is also worth to note that pokkali systems in Kerala received geographical indication (GI) tagging which provided further possibility for obtaining a premium price (Anonymous, 2013). 
Quality shrimp seed is the primary critical input and it was reported that the quality of free shrimp seed supplied by the Govt. of Kerala was poor. In order to enhance the productivity of traditional farms in Kerala the Govt. may support the farmers with provision of quality feeds, other supplements and capacity enhancement. In case of West Bengal, the Department of Fishers may mobilise the farm youth and conduct skill development courses on scientific shrimp farming for enhancing their capacity. Considering the above, it is suggested that appropriate extension efforts are needed to impart the required technical skills, quality inputs and diagnostic services to enhance the productivity of traditional shrimp farming systems. The results of the study indicated that the production system in-terms of traditional or scientific and their respective productivity are connected in tune with their operational protocols. Since shrimp aquaculture needs technical skills irrespective of their size of operations, irrespective of the socio-personal profile of respondents the information sourcing was similar and hence there was no relationship between the profile and access to information. Further, productivity of the system and access to information were closely connected may be because the investments incurred in the farming were relatively high in case of scientific systems and the farmers were looking for additional information to obtain a successful crop. This may be reason to notice that even a small scale scientific farmer had better information access than large scale traditional farmer.
In the light of the above, aquaculture extension agencies are expected to provide the critical access to the knowledge, information and technology that farmers require to improve their farm productivity and advance their economic status. Private input companies and progressive farmers are the major extension workers in scientific shrimp farming and DoFs are playing key role in subsidy oriented welfare extension in traditional farming areas. However, none of the agency/institution could exclusively or independently cater the information and skill requirements of different segments of aquaculture systems and different strata of farmers in the aquaculture sector. Therefore, the better approach is collaboration/ partnership between the institutions/ agencies, strengthening DoFs and integration of information channels especially mobile phone based interfaces and harnessing ICT medium for effective aquaculture extension service.

\section{CONCLUSION}

The study indicated that the profile status of the aqua farmers and the production parameters of brackishwater aquaculture systems across the states were dissimilar in terms of production. However, the systems were profitable in tune with the investments made and technology adopted. The traditional systems need 'system specific technology package' to enhance their productivity and sustainability. Traditional systems need adequate extension service support for skill enhancement, quality inputs and better diagnostics and management measures. The 
state fisheries departments should partner with research institutions and input companies respectively for technology support and reaching the farmers located in remote locations. Mobile phone applications may be developed and launched for connecting the technology, inputs, services and market with the farming community.

\section{REFERENCES}

Anonymous. (2013). Shrimp, fish and paddy cultivation in same field is lucrative, Aqua International, June 2013: 11-12

Bhattacharya.P. (2009). Economics of shrimp farming: a comparative study of traditional vs. Scientific shrimp farming in West Bengal, Working paper 218, Institute for Social and Economic Change, Bangalore.

Chandrasekaran, V.S., Shanthi, B., Kumaran, M., \& Krishnan, M. (2009). Shrimp farming practice in Goa, India. Fishing Chimes, 29 (8): 7-10 .

Kiran, R.B. \& Salim, S. (2012). Shrimp Aquaculture: Diseases, Health Management, Exotic Introduction and Regulations. Manual on World Trade Agreements and Indian Fisheries Paradigms: A Policy Outlook, CMFRI, Kochi,, 425-428 